УДК 331.820:677

M.I. Сергіснко, ст. викладач, ORCID 0000-0001-8284-9072

В.Г. Смоляр, інженер, ORCID 0000-0002-0355-0353

Д.О. Соколенко, студент

М.В. Назарець, студент

Національний технічний університет України «Київський політехнічний інститут імені Ігоря Сікорського»

\title{
ЗАСТОСУВАННЯ СИСТЕМИ КОНДИЦІОНУВАННЯ ПОВІТРЯ ЯК СПОСІБ ПІДВИЩЕННЯ ЕФЕКТИВНОСТІ ТКАЦЬКОГО ВИРОБНИЦТВА, ПОКРАЩЕННЯ УМОВ ПРАЦІ ТА ЗМЕНШЕННЯ ВПЛИВУ НА ДОВКІЛЛЯ
}

\begin{abstract}
Проблема захисту довкілля від забруднень включає проблему захисту виробничого середовища від шкідливих технологічних викидів. Великого значення набуває дане питання в розробленні нових технологій для покращення якості виробів, зростання екологічної чистоти текстильної продукції, екологічної безпеки виробничого процесу, покращення умов праці та захисту здоров'я працівників.

Ключові слова: текстиль, пиловловлюючі пристрої, кондиціювання повітря, повітрообмін, рециркуляція, зволожене повітря, енергозбереження, ентальпія, охорона праці, охорона довкілля.
\end{abstract}

Вступ. Ресурсо- і енергозбереження та оздоровлення навколишнього природного середовища це дві сторони єдиного процесу досягнення еколого-економічної збалансованості у функціонуванні національної економіки. В сучасних умовах значної актуальності набувають питання захисту працівників від шкідливого впливу виробничого середовища, покращення умов праці, зменшення забрудненості довкілля, підвищення ефективності ткацького виробництва. Дотримання гігієнічних вимог до мікроклімату виробничих приміщень дозволяє створювати на робочих місцях здорову, сприятливу для організму людини обстановку, безпечне середовище перебування, за мінімальних витрат на його підтримання $[1,3]$.

На сьогодні проблеми зниження забрудненості повітря, захисту працівників від небезпечної дії шкідливих речовин та шуму, зменшення впливу на довкілля частково вирішуються застосуванням видалення шкідливих речовин за допомогою вентиляційних систем, удосконаленням технологічного процесу, використанням індивідуальних засобів захисту людини, за допомогою організаційних методів роботи тощо [1,2].

Текстильне виробництво потребує значних витрат енергії та води для свого функціонування. Його характерною особливістю є повсюдне виділення пилу, який утворюється під час переробки та виготовлення текстильних матеріалів і являє собою мікрочастинки волокна. При формуванні синтетичних ниток у повітря також виділяються шкідливі речовини. Через незначну масу вони знаходяться тривалий час у повітрі, в зваженому стані. Супроводжуючи весь технологічний цикл, волокнистий пил заважає нормальному протіканню технологічного процесу, забруднює виробниче середовище і значно впливає на здоров’я працівників, умови та безпеку праці. Як наслідок, знижується продуктивність устаткування і якість продукції, що випускається. Серед апаратників формування капронових ниток захворюваність органів дихання перевищує в 3 рази показники у порівнянні з безпечними умовами праці [3]. Отруйний пил, що видаляється, через застосування недостатньо ефективних методів фільтрації також забруднює навколишнє середовище [4]. Досягти значного зниження впливу шкідливих чинників на здоров'я людини, мінімізувати забруднення довкілля, запобігти проникненню шкідливих речовин у повітря робочої зони, 3 одночасним скороченням витрат енергії та водних ресурсів, підвищити продуктивність ткацького виробництва та якість продукції, що випускається, можливо лише застосуванням комплексного підходу до вирішення існуючих проблем.

Мета та завдання. Метою дослідження є розроблення комплексного підходу до вирішення проблеми зниження забрудненості повітря, захисту працівників ткацького виробництва від небезпечної дії шкідливих речовин та шуму, зменшення впливу на довкілля, на основі застосування автоматизованої системи кондиціювання повітря.

Викладення основного матеріалу дослідження.

Комплексний підхід включає використання сукупності типових методів нормалізації повітряного середовища [3], які базуються на раціональному використанні досконалих виробничих технологій.

(C) М.І. Сергієнко, В.Г. Смоляр, Д.О. Соколенко, М.В. Назарець, 2017 


\section{ISSN 1813-5420 (Print). Енергетика: економіка, технології, екологія. 2017. № 4}

Реалізація його можлива із застосуванням автоматизованої системи кондиціонування повітря (СКП) для підтримання заданих температури, вологості, чистоти і швидкості руху повітря, різниці повітря в приміщенні і приточного, зниження рівня шуму, створюваного роботою устаткування СКП .

Для зменшення забрудненості в робочій зоні необхідно застосувати найбільш ефективний спосіб очищення повітря від пилу. Це забезпечить значне покращення умов праці персоналу. При грубому очищенні вловлюється лише крупний пил з розміром порошинок понад 100 мкм. При тонкому очищенні вловлюється найбільш небезпечний дрібний пил з розміром частинок менше 10 мкм. Для вирішення поставленої задачі найбільш доцільним $є$ застосування мокрих пиловловлювачів, у яких частинки змочуються або прилипають до мокрих поверхонь [4,5].

Об’ємні витрати кондиційного повітря для провітрювання приміщення ткацького цеху

$$
L_{o}=L_{p .3}+\left[3,6 Q_{\text {изб }}-\rho L_{p .3}\left(i_{p .3}-i_{n}\right)\right] / \rho K_{L}\left(i_{p .3}-i_{n}\right) \text {, }
$$

де $L_{p .3}-$ кількість повітря, що видаляється з робочої зони, Для забезпечення підпору в ткацьких цехах $L_{p .3}$ $\leq 0,9 L_{o}, \mathrm{M}^{3} /$ год; Qндл - надлишковий тепловий потік повного тепла в приміщенні, Вт; $\rho$ - густина повітря, кг $/ \mathrm{M}^{3} ; i_{p .3}, i_{n}$ - ентальпія повітря, відповідно в робочій зоні, а також, що подається в приміщення, кДж/кг; $K_{L}$ - розрахунковий або експериментальний коефіцієнт повітрообміну.

Згідно (1) повітряна витрата кондиційного повітря $K_{L}$, зменшується зі зростанням коефіцієнту повітрообміну і підвищується з його зменшенням, для вибраного способу організації повітрообміну.

Коефіцієнт повітрообміну

$$
K_{L}=\left(i_{y}-i_{n}\right) /\left(i_{p .3}-i_{n}\right)=\mathrm{y} / \alpha
$$

де $i_{y}$ - ентальпія повітря, що видаляється з цеху; $\mathfrak{y}$ - коефіцієнт використання приточного повітря; $\alpha-$ коефіцієнт виділення тепла в робочу зону.

В цехах з тепловиділенням коефіцієнт повітрообміну

$$
K_{L}=\left(t_{y}-t_{n}\right) /\left(t_{p .3}-t_{n}\right) \text {, }
$$

де $t_{y}, t_{n}, t_{p .3}$ - температури повітря відповідно: того, що видаляється з цеху, та того, що подається в цех, в робочій зоні, ${ }^{\circ} \mathrm{C}$.

У СКП (рис.1) кондиціювання повітря здійснює центральний кондиціонер 1, який подає зовнішнє повітря або суміш зовнішнього і рециркуляційного повітря через канали 2 у верхню зону ткацького цеху 10.

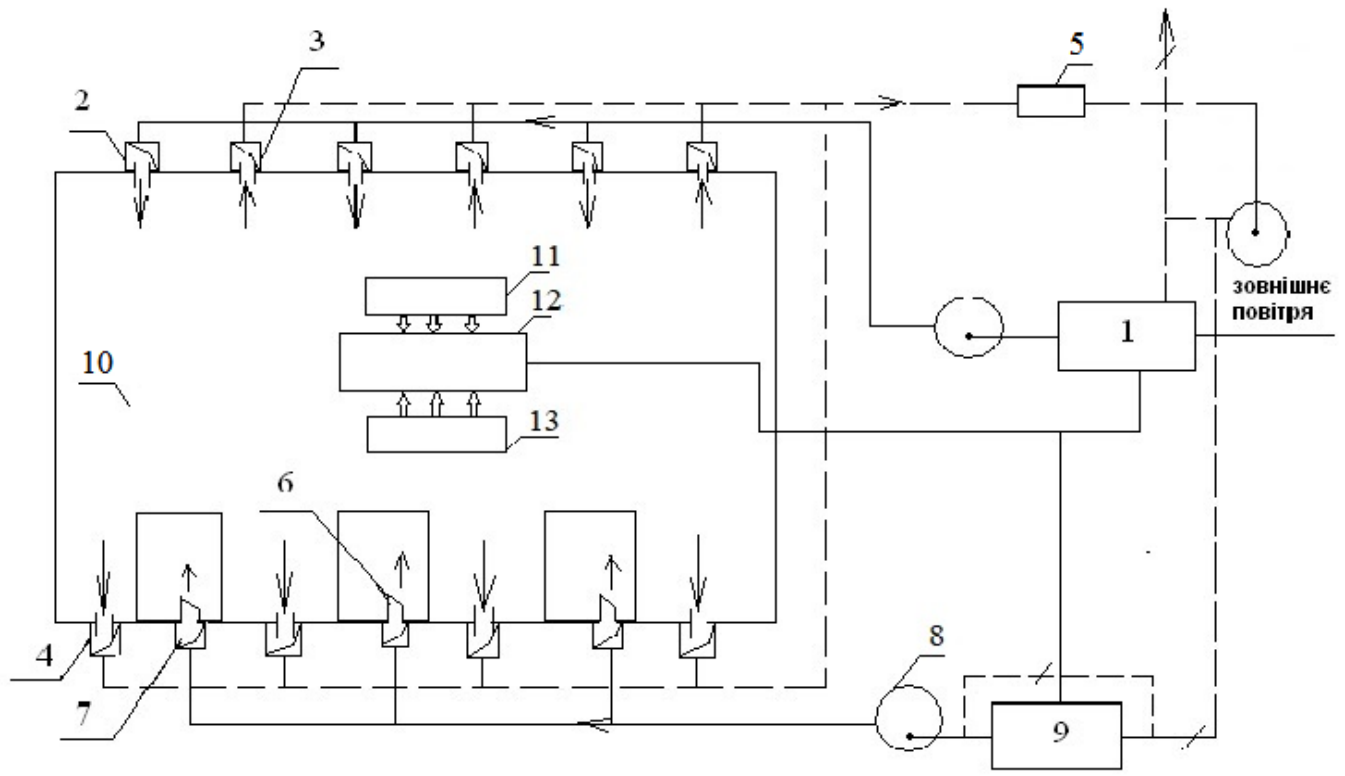

Рисунок 1 - Система кондиціювання повітря ткацького цеху. 1 - центральний кондиціонер; 2,3- канали у верхній зоні цеху; 4 - канал у нижній зоні цеху; 5 - фільтр; 6 - насадки; 7 - повітропровід; 8 вентилятор; 9 - камера зрошування; 10 - приміщення ткацького цеху; 11,13 - датчики контролю; 12 блок керування. 
Ефективність пиловловлювання та якості повітря зростає з підвищенням відносної вологості в технологічній зоні ткацького верстату, і в тому числі - при зміні асортименту й лінійної щільності пряжі. Оптимальні параметри повітря в технологічній зоні верстата забезпечуються центральною системою кондиціювання з подачею зволоженого рециркуляційного повітря.

Видалення повітря проводиться 3 верхньої зони через канали 3, а з нижньої через канали 4. Очищення повітря, що видаляється, від пилу здійснюється за допомогою фільтра 5. Мікроклімат у технологічній зоні верстата досягається шляхом обдування зволоженим рециркуляційним повітрям через розміщені у верстатах насадки 6. Зволожене повітря до насадок подається через повітропровід 7 вентилятором 8. Зволоження рециркуляційного повітря здійснюється в камері зрошування 9 [6,7].

Витрата зволоженого повітря розраховується за формулою:

$$
\Sigma \mathrm{G}_{\mathrm{cr}}=\Sigma\left(\mathrm{G}_{\mathrm{cr}} \mathrm{n}\right),
$$

де $\mathrm{G}_{\text {ст }}$ - витрата повітря на верстат, кг/годину; $\mathrm{n}$ - кількість верстатів.

Рециркуляційне повітря, проходячи витяжну систему і систему зволоження, нагрівається приблизно на 1,0 кДж/кг.

Регулювання відносної вологості зволоженого рециркуляційного повітря стало можливим завдяки зміні кількості води, що розбризкується в камері зрошування, та залежить від кратності повітрообміну (рис. 2), що є перевагою даної СКП.

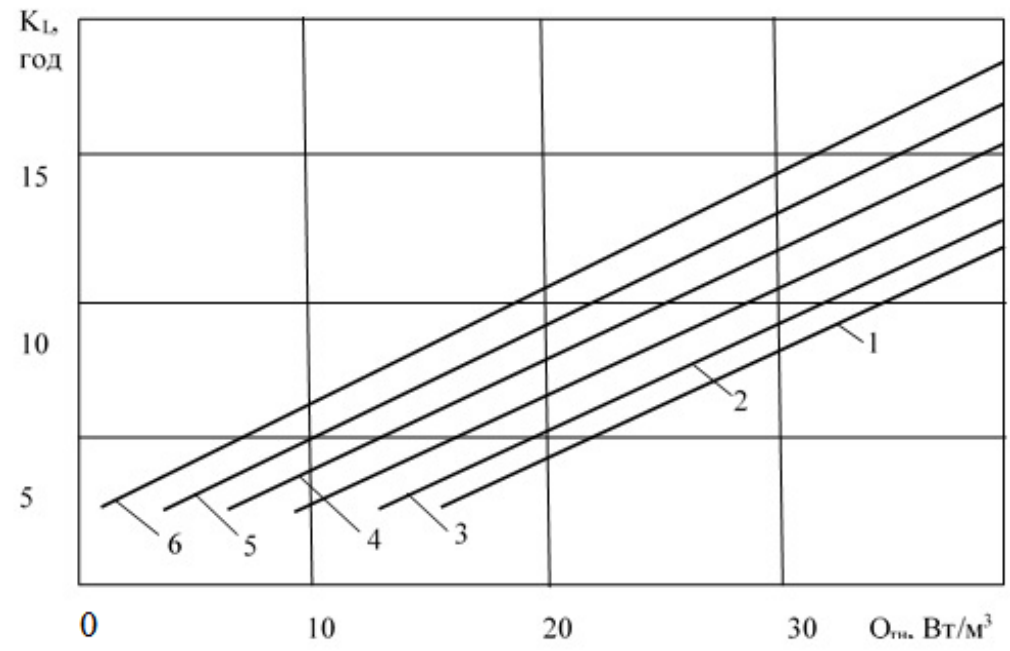

Рисунок 2 - Залежність кратності повітрообміну від теплонапруженості:

1 - кількість зволоженого повітря при $\mathrm{L}_{\mathrm{cr}}=0,2$ - кількість зволоженого повітря при $\mathrm{L}_{\mathrm{cr}}=15 \mathrm{~m}^{3} /$ год, 3 кількість зволоженого повітря при $\mathrm{L}_{\mathrm{cr}}=50 \mathrm{~m}^{3} /$ год, 4 - кількість зволоженого повітря при $\mathrm{L}_{\mathrm{cr}}=130 \mathrm{~m}^{3} /$ год, 5 - кількість зволоженого повітря при $\mathrm{L}_{\text {ст }}=200$ м $3 /$ год, 6 - кратність повітрообміну, що не залежить від кількості зволоженого повітря.

Система забезпечує найбільш сприятливі параметри внутрішнього повітря: від центрального кондиціонера - в робочих зонах для комфортного самопочуття обслуговуючого персоналу і в зоні технологічного процесу - від місцевого кондиціонера. Крім того, зменшується потрібна продуктивність центральних кондиціонерів у 2-3 рази, в порівнянні з традиційними центральними СКП [1], що дозволяє скоротити затрати енергії. Витрати приточного повітря в ткацьких цехах для однакових тепловитрат $Q н а д л=500 \kappa \mathrm{KT}, i_{p, 3}-i_{n}=10$ кДж/кг, $\rho_{\mathrm{n}}=1,2$ кг/ ${ }^{3}$. Дані для порівняння наведено в табл. 1 у формі показника відносної витрати $L_{o}$ приточного повітря. Найбільш нераціональне використання приточного повітря простежується у варіанті 1, де від 33 до $66 \%$ приточного повітря не використовується. Найбільш ефективним є повітрообмін у десятому варіанті. При цьому можливе суттєве скорочення (до 24\%) подачі повітря в робочу зону.

Ресурсо- і енергозбереження та. що змінюються в часі (за певною програмою). Способи організації повітрообміну на текстильних підприємствах характеризуються відносно невеликими значеннями його коефіцієнтів повітрообміну (табл.1). 
ISSN 1813-5420 (Print). Енергетика: економіка, технології, екологія. 2017. № 4

Таблиця 1 - Коефіцієнти повітрообміну для різних способів провітрювання

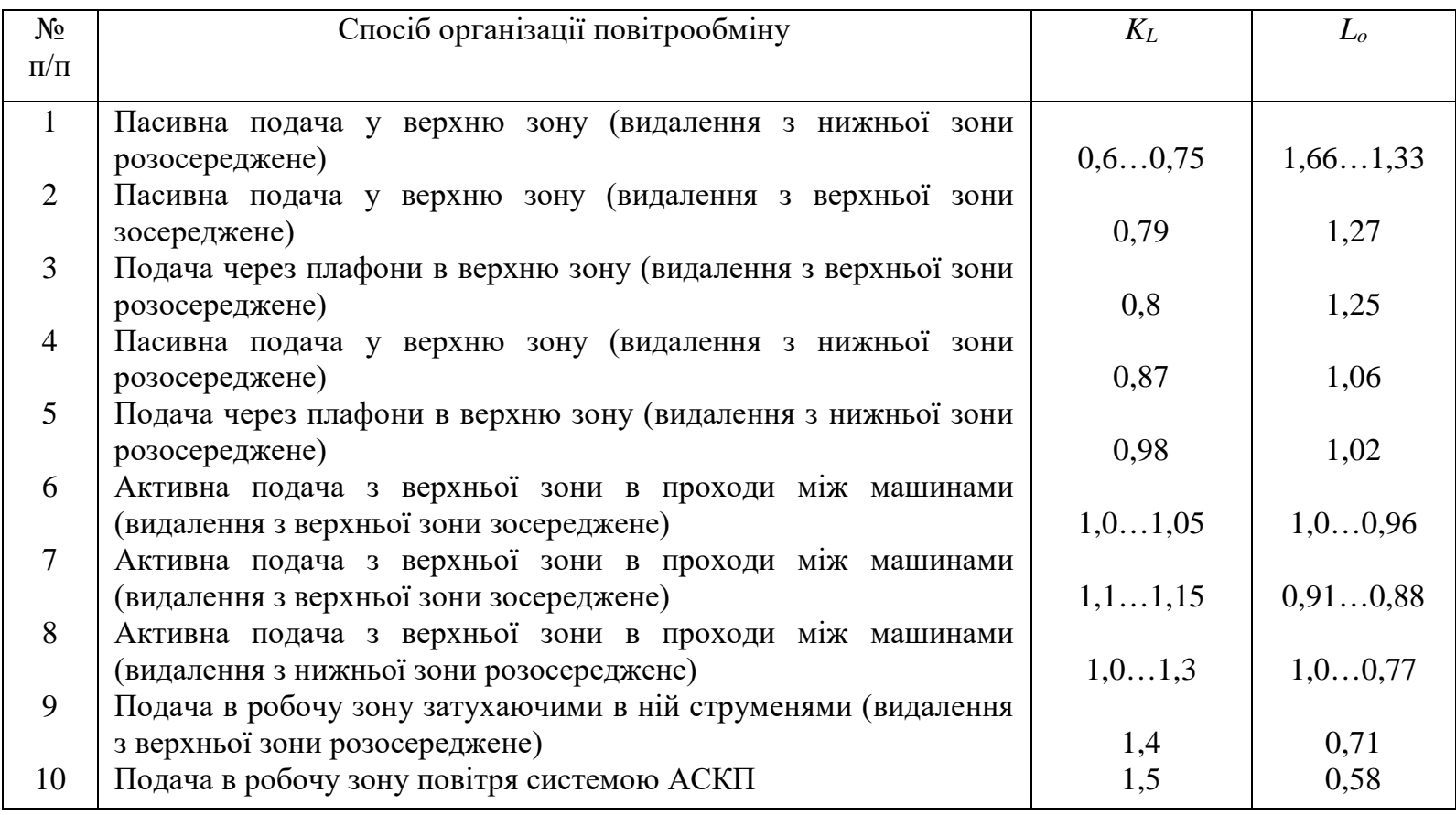

Результати досліджень отримані на прикладі ткацького цеху з верстатами АТПР - 120 при подачі зволоженого повітря із розрахунку $\mathrm{L}_{\mathrm{cr}}=75 \ldots 200 \mathrm{~m}^{3} /$ годину на 1 м ширини навою [6]. 3 рис. 2 видно, що кратність $K_{p}$ повітрообміну збільшується пропорційно підвищенню теплонапруженості $Q_{\text {тн }}$ в цеху. Кратність повітрообміну по повітрю, що видаляється (лінія 6), не залежить від витрати зволоженого повітря, що подається на 1 м навою, але в цілому збільшується приблизно на 3 \% в порівнянні $з$ системою кондиціювання без подачі зволоженого циркуляційного повітря. Це пояснюється надмірним теплом, що поступає від вентиляторів витяжної установки системи зволоження. Ефективність очищення повітря від пилу в зоні роботи працюючого персоналу ткацького цеху при залежить від технологічної схеми пиловловлювання та кондиціювання приточного повітря [8,9]. Застосування зволоженого повітря знижує на 30-40 \% вміст технологічного пилу в зоні роботи персоналу, підвищує продуктивність, покращує охорону здоров’я та праці, промислову безпеку.

Подальше вдосконалення автоматизованої системи кондиціювання повітря (АСКП) можливе шляхом застосування комп'ютера керування з сервером баз даних, комплекту датчиків та мережевих контролерів, з якими можуть бути пов'язані спеціалізовані виконавчі контролери мережі [1]. На рис.3 наведено графіки залежності ефективності застосування різних систем кондиціювання повітря.

Підвищення ефективності ткацького виробництва , економія енергії найбільша у разі застосування розробленої системи АСКП (крива 3) .

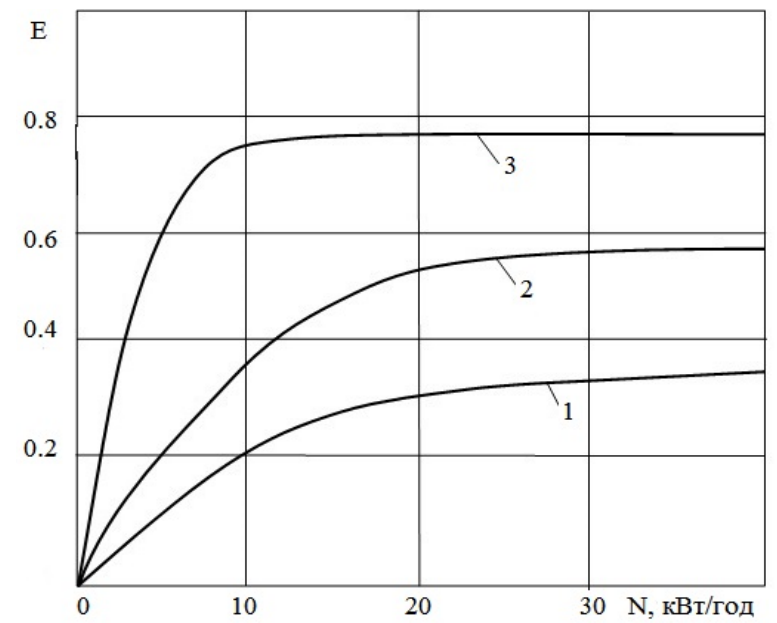

Рисунок 3 - Ефективність застосування систем кондиціювання : 1 - традиційна; 2 - комбінована зі зволоженням повітря; 3 - автоматизована 
Екологічнй (природоохоронний) ефект енергозбереження обмежується не лише сферою використання енергії. Кожна заощаджена при використанні одиниця палива, гігакалорія теплоносія чи заощаджена кіловат-година електроенергії дозволяють також забезпечити значний природоохоронний ефект на всіх попередніх енергетичних стадіях. Заходи з природоохоронної діяльності повинні скоротити обсяги викидів шкідливих речовин в атмосферу, стабілізувати обсяги води, яка використовується на промислові потреби, з одночасним скороченням питомого водоспоживання. Слід враховувати, що ресурсо та енергозбереження можна забезпечити в рамках будь-якої існуючої системи керування технологічним процесом з урахуванням впливу на довкілля.

Основні технічні рішення розробленої АСКП були перевірені в умовах ткацьких підприємств міст Фастова та Броварів. Отримані результати в основному підтвердили правильність теоретичних положень та доцільність застосування АСКП на підприємствах текстильної промисловості.

\section{Висновки}

1. Застосування комплексу методів нормалізації повітряного середовища, використання пиловловлювальних пристроїв у поєднанні зі зволоженням повітря дає можливість підтримувати в робочій зоні допустимі мікрокліматичні умови на період восьмигодинної робочої зміни згідно санітарногігієнічних норм, а також зменшує забруднення довкілля.

2. Система кондиціювання з подачею зволоженого циркуляційного повітря в технологічну зону забезпечує стабільні оптимальну вологість і температуру, що дозволяє підвищити ефективність роботи обладнання та зменшити виділення пилу. При цьому подачу кондиційного повітря в цех можна зменшити на 20 - 30\% у порівнянні з традиційними способами та на 30-40\% знизити забруднення повітря в робочій зоні. Поряд з цим зменшується рівень шуму за рахунок підтримання менш напружених режимів роботи вентиляційного устаткування.

3. Застосована технологічна схема 3 подачею зволоженого циркуляційного повітря та кондиціювання повітря з АСКП на ткацькому підприємстві дозволить підвищити якість продукції, умови роботи персоналу, зменшити забруднення довкілля, а також знизити витрати води та енергоносіїв.

\section{Список використаної літератури}

1. Закладний О.М. Системи управління і контролю мікроклімату у виробничих приміщеннях / О.М.Закладний, С.Л.Прядко, В.Г.Смоляр // Збірник матеріалів третьої науково-методичної конференції «Проблеми охорони праці, промислової та цивільної безпеки - К.: НТУУ «КПІ», 2009. С.57-60.

2. Закладний O.M., Використання сучасних систем управління мікрокліматом промислових приміщень - складова підвищення ефективності та безпеки праці / О.М.Закладний, С.Л.Прядко, В.Г.Смоляр // Наукова конференція «Охорона праці та соціальний захист працівників - К.: НТУУ «КПІ», 2008. С.13-15.

3. Ткачук К.Н. Розробка комплексу методів нормалізації повітряного середовища апаратників формування капронових ниток / К.Н.Ткачук, Л.О. Мітюк // Збірник матеріалів третьої науково-методичної конференції «Проблеми охорони праці, промислової та цивільної безпеки» - К.: НТУУ «КПІ», 2009. С.1011.

4.Звіт по інвентаризації джерел викидів забруднюючих речовин в атмосферу на ВАТ "Чернігівське Хімволокно". - Чернігів, 2001. - 101 с.

5. Сергієнко М.I. Підвищення охорони праці ткацького виробництв за рахунок впровадження нових систем кондиціювання/ М.І.Сергієнко, Є.А. Бахтіна // Збірник наукових праць "Проблеми охорони праці на Україні ”. Національний НДІ промислової безпеки та охорони праці. - К.: ННДІПБОП. - 2010. -№19. C.48-55.

6. Халезов Л.С. Очистка запыленного воздуха на текстильных предприятиях / Л.С. Халезов., Ю.А. Шиков, А.Г. Чесноков //. - М.: Легкая и пищевая промышленность, 1981. - 136 с.

7. Пирумов А.И. Обеспылевание воздуха / А.И. Пирумов . - М.: Стройиздат, 1981. - 296 с.

8. Коротаев А.М. О снижении запыленности воздуха в ткацком цехе / А.М.Коротаев // Изв.вузов. Технология текстильной промышленности. - 1987. - № 1 - С. 93

9. Нимич Г.В., Михайлов В.А., Бондарь Е.С. Современные системы вентиляции и кондиционирования воздуха.- К.: Тов “Видавничий будинок” Аванпост-Прим.” 2003. - 630 с. 
M. Sergienko, Assos. Prof. ORCID 0000-0001-8284-9072

V. Smolyar, ORCID 0000-0002-0355-0353

D. Sokolenko, student

M. Nazarets, student

National Technical University of Ukraine “Igor Sikorsky Kyiv Politechnic Institute” APPLICATION OF AIR CONDITIONING SYSTEM AS A METHOD OF INCREASING THE EFFICIENCY OF TEXTILE PRODUCTION, MANAGEMENT OF WORK CONDITIONS AND STORAGE OF ENVIRONMENTAL IMPACT

The Problem protection of environment from contamination includes and problem of protection of the production ambience from bad technological surge. Special importance gains the question about development new technology, directed on improvement quality product, increasing of the ecological purity to finished products and ecological safety of the production process.

The article deals with the actual issues of preservation of the natural environment and ensuring of the normal working conditions of workers of the enterprises of the textile industry, resource and energy saving in these enterprises, which is achieved by applying an integrated approach with the use of progressive technologies, are the main factors of the process of achieving ecological and economic equilibrium in the functioning of the national economy.

The solution of the problems is possible by applying systems of monitoring and automation of production processes of textile production, and above all - air conditioning, using automated systems. The developed automated air conditioning system at the weaving plant will improve the quality of products, working conditions, reduce environmental pollution, and reduce the consumption of water and energy.

Надійшла 21.11.2017

Received 21.11.2017

УДК 621.3:614.8

Є.А. Бондаренко, д-р техн. наук, доц. O.Є. Рубаненко, канд. техн. наук, доц.

Н.О. Манжак

Вінницький національний технічний університет

\title{
УДОСКОНАЛЕННЯ ПРИНЦИПУ ПОБУДОВИ СУЧАСНОЇ СИСТЕМИ МЕНЕДЖМЕНТУ ЕЛЕКТРОБЕЗПЕКИ НА ЕЛЕКТРИЧНИХ СТАНЦІЯХ, ПІДСТАНЦІЯХ ТА МЕРЕЖАХ НАДВИСОКИХ КЛАСІВ НАПРУГИ
}

\begin{abstract}
Розглянуто найбільш розповсюджені підходи європейських систем менеджмету різних напрямів діяльності та сфер управління. Розроблено структурну модель системи управління електробезпекою та алгоритм аналізу ризику електротравматизму. Це дозволило запропонувати принцип функиіонування системи електробезпеки електротехнічного персоналу, що обслуговує енергетичні установки на станціях, підстанціях та електричних мережах надвисоких класів напруги. Запропонований принцип управління системою електробезпеки від дії електричної енергї оснований на замкнутому інформаційному контурі, який містить послідовність логічно пов'язаних функцій управління: оцінювання ризику ураження персоналу електричною енергією; планування та виконання планових заходів 3 електробезпеки щзодо усунення ланцюга передумов появи електротравм, направлених на мінімізацію ризику електротравматизму; контроль за виконанням планових заходів; оцінювання та аналіз ризику електротравматизму після вжитих заходів; ухвалення рішень із вдосконалення системи електробезпеки.

Ключові слова: електрична станція, енергія, електричне поле, менеджмент, ризик, електробезпека.
\end{abstract}

(C) Є.А. Бондаренко, О.С. Рубаненко, Н.О. Манжак, 2017 